\title{
切削工具材料の押込み試験における 破壊の発生挙動*
}

\author{
柴 坂 敏 郎** 橋 本 英 文*** \\ Experimental Simulation of Brittle Failure Initiation \\ by Indentation Test for Cutting Tool Materials \\ Toshiro Shibasaka and Hidefumi Hasimoto
}

\begin{abstract}
The behavior of crack initiation, which results in the brittle failure during the cutting, was simulated experimentally by indentation test techniques for cemented carbide cutting tool materials. In indentation test the cracks were observed at a short distance from indenter-specimen contact zone, and at the center of that contact zone. For the former crack path was grain boundary of carbides and interface of carbide particle and cobalt binder, and the latter propagated in carbide particles mainly. Indenting load at which crack occurred decreased with a increase in the number of indenting cycles, and was affected by tool materials and surface preparations. From the comparison of indentation test with transverse rupture test about fracture source and stress distribution, it was considered that in case of stress concentration such as indentation test fracture originated in carbide grain boundaries and carbide particle-binder interfaces, in the other case such as transverse rupture test fracture initiated from a pore or a coarse grain. The appearance of fracture surface and the stress distribution of the brittle failure of cutting tools is similar to those of indentation test, then it is seemed that the crack, which results in brittle failure, occurs at grain boundaries and interfaces, and grows.
\end{abstract}

Key words: brittle failure, cutting tool, indentation test, crack initiation, transverse rupture test, cemented carbide

\section{1. 緒 言}

切削工具材料として主要な材料である超硬合金の強 度についてはこれまでに多くの研究がなされていると ともに，最近では，切削加工の信頼性向上や自動化で 特に問題となるぜい性損傷に対して多くの㭘討がなさ れ，加工条件や工具材料の選定あるいは材料の改良， 開発に対して有益な知見が得られている，特に，強度 評価によく用いられる曲げ強さは材料内の粗大ポアや 粗大粒子などの先在欠陥の大きさ，位圈などに依存す ることが明らかにされ゙，線形破壊力学の手法を適用 して強度の定量的検討がなされるとともに21，欠陥を

* 原稿受付 昭和63年 5月26日. 昭和58年度精機学 会秋季大会学術講演会（昭和58年10月15日）にて 発表

** 正 会 員 福井大学工学部 (福井市文京3-9-1) *** 正 会 貣 久留米工業大学 (久留米市上津町)
小さくするよう製造上の改畕がなされている.

しかしながら、破俵の発生權檕については十分解明 されていない。すなわち，ぜい性損傷では切削中の工 具にき裂が観察されているものの, 破面観察いによる とポアなどの明らかな欠陷が制察されないことが多く， 破壤発生の起点が曲げ試験時とは異なる場合がある. また，欠陷を起点とする破墙でも小さな欠陷では曲代 強さがその大きさに依存しなくなることが指摘されて おり21，ぜい性損倁や工具材料の強度を考える場合，

破堙の発生機構を明らかにすることが重要となる。

そこで、本研究ではぜい性損伤時における破轅の発 生機構を明らかにすることを目的として，まず工具材 料への押迈み試験時に発生するき裂に着目し，その発 生權構について検討する，すなわち，ぜい性損傷は過 渡的切削過程で発生することから工具境界条件が副々 変化し，き裂発生時の力学的検討を行うことは容易で はない，また，切りくずの付普，应耗などにより工具 すくい面上での十分な觀察は行えない，そこで，本報 


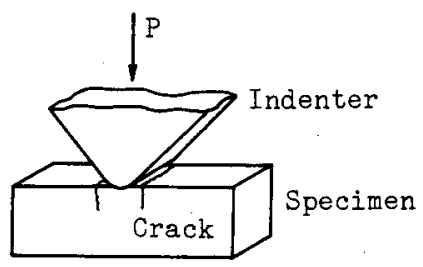

Fig.1 Schematic illustration of indentation test

告では工具材料への押込み試跧によりき裂を発生させ， 破面解析，押込み荷重，工具材料などの点からき列の 発生誉動について朁郡した結果を報告する。

\section{2. 押込み試臨方法}

切削工具材料におけるき裂の発生挙䡃についてはビ ッカース压痕コーナからのき裂4，球の押付け時にお ける放射状あるいはリング状き裂らなどに基ついて模 討されている．前者は圧子の角部からのき致であり， 切削场では压子に相当するものは考えられない，また， き裂の伝擂過程を観察しているのであって，発生時を 覞察しているのではない，球の押付けではき裂形状が リング状であること，また，工具材料はガラスなどの ように透明ではないことからき裂深さ（長さ）の测定 も容易ではなく，微視的模㣙をする場合その形状から 破面解析は困耤となる.

そこで、ここでは四1に示す円柱状圧子の被武卧工 具への押込み試联を行った。これは先端が円柱状の圧 子を用いることから発生するき裂は二次元的であり， 切削時の工具一切りくずのすくい面上での接触状照に より近いものとして想定した。この方法では試料例面 の研削・研唐によりき列長さの測定および長さ方向の 微視的穜察が容易に行えるとともに，押込み時に発生 したき裂が先在欠陥より大きい場合、三点曲げを行う とこのき裂を起点として破断し，押込み時に発生した き裂の破面䚈宗も行える.

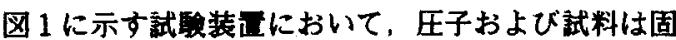
定具を介してダイセットに組み込み，ダイセット上の ロードセルにより荷重を測定した，具荷には油圧ブレ スを用いた，压子材料には超硬合金 P20看を用い，先 端半径は $1.2 \mathrm{~mm}$ とした。

供試材料は超硬合金工具材料 $\mathrm{K} 10$ 種の 2 種類，およ びP10，P20，P30種で，K10種の 2 程類 $(\mathrm{K} 10 \mathrm{~A}, \mathrm{~K} 10 \mathrm{~B})$ は 图2に示すように粒度が買なる，武料寸法は高さ7 ma， 幅3 $\mathrm{mm}$ ，長さ30mmのもの，およびスローアウェイ型工具 $(\square 12.7 \times 4.8 \mathrm{~mm})$ を用いた。なお，試料の押込み面と

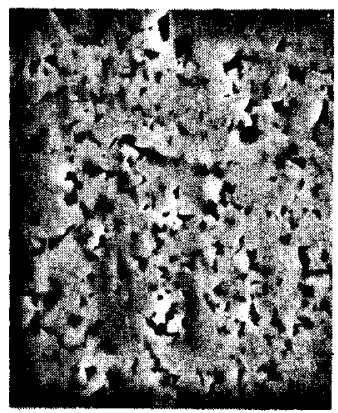

(a) K10A

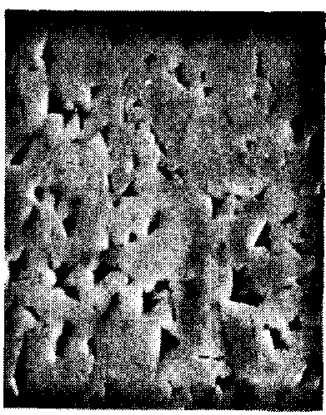

(b) $\mathrm{K} 10 \mathrm{~B} \stackrel{2 \mu \mathrm{m}}{\longrightarrow}$
Fig.2 Microstructures of K10

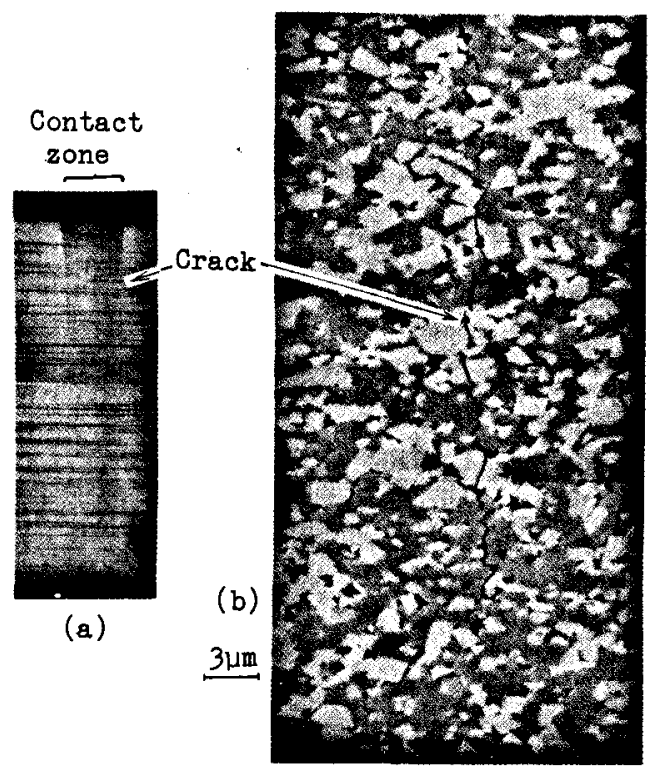

Fig.3 An example of observed crack in the indentation test Tool material; P2O

両側面の角は $0.5 \times 0.5 \mathrm{~mm}$ の面とりを施し、試料長手

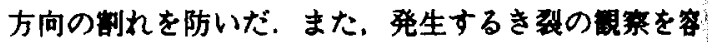
易にするため，押込む面はダイヤモンドペーストで就 面に仕上げた。

\section{3.武聡鈷果および考察}

\section{1 発生き致の微視的形意}

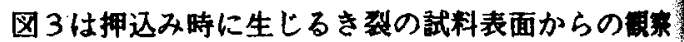

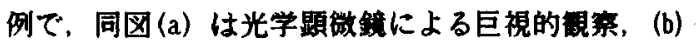

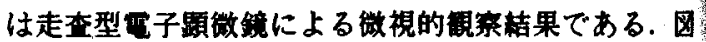
3(a) より試料湖面近傍で三次元変形と考えられる依 子も見られるが，圧子外㑡近傍でほは試料幅全体にか 


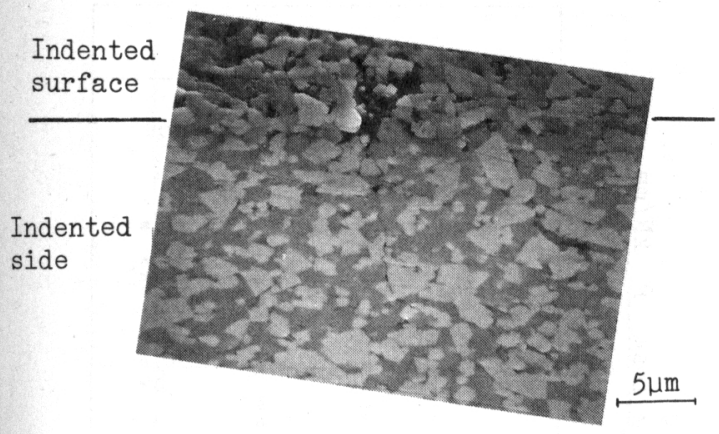

Fig. 4 Observation of a crack in cross section of the indented specimen Tool material; P2O

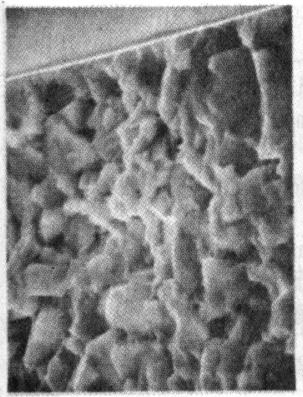

(a)

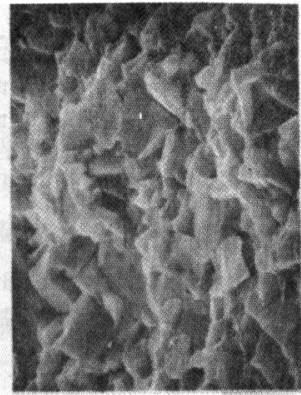

(b)

$2 \mu \mathrm{m}$
Fig.5 Examples of fracture surface (a) Fracture surface due to indentation test, (b) Fracture surface due to transverse test Tool material; P20

たって一様なき裂を生じていることがわかる，き裂は 巨視的には直線的であるが, 微視的に見ると炭化物粒 界に依存して波状となり, 主に, 炭化物粒界あるいは 炭化物とCo相との界面を伝播していることがわかる。

次に, 図4は試料側面加ら研削・研磨し, 試料内部 でのき裂を深さ方向に観察した例である。き裂は試料 内部で，押込み方向から遠ざかる方向に伝播する傾向 を示していることがわかる，同図では十数 $\mu \mathrm{m}$ のき裂 が観察されている。

さらに，困5は押込み試験後，三点曲げにより試料 を破断させ，押込みによるき裂の破面（同図(a))およ び比較のためこの三点曲げ時に生じた破面（同図(b)) を観察した例である，同図(a) の破面では炭化物表面 上にCoが観察され，き裂が炭化物粒界あるいは炭化物 と結合相との界面を伝播したと考えられるのに対し，

(b)ではリバーパターンが観察され, き裂が炭化物粒 内を主に伝播していることがわかる。これは押迈みに

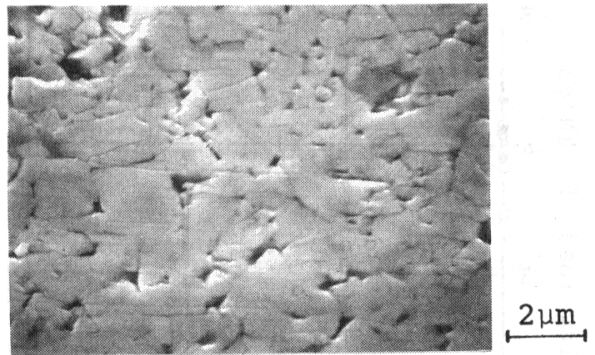

Fig.6 An example of the surface observation of indenter-specimen contact zone Tool material; P20

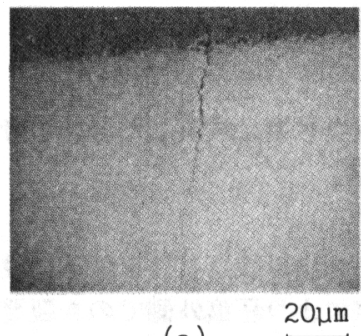

(a)



(b) $\stackrel{2 \mu \mathrm{m}}{\longleftarrow}$
Fig.7 A crack observed in the indenterspecimen contact zone (a), and it's fracture surface (b)

Tool material; P2O

よるき裂は速度が逮く粒界や界面を伝播するのに対し， 曲げ試驗時の不安定き裂の伝播速度が速く粒内を伝播 するという伝播速度の変化が一因と考えられる。この ことは疲労き裂が粒界を伝播し, 疲労き裂からの不安 定き裂の伝播経路が粒内になることと対応している31.

一方，庄子と接触する試料表面においてもき裂が観 察される.図6は圧子との接触領域の試料表面観察例 であり、粒内割れあるいは粒界割れが観察される。こ の場合，割れは粒径程度の大ささであり，圧痕外側の 図3に示したような特定方向の長いき裂は観察されな い.しかし，繰返し負荷を与えると，図7 (a) に示す 粒径以上の明らかなき裂が観察された。同困の場合絽 返し数は 400 回であり，前述と同粎にこのき裂の破面 について観察した例を龱7 (b) に示している. 同図に おいてリバーパターンが観察されることから、きが 粒内も伝播することがわかる。これは，前述の圧痕外 側近傍とはき裂の微視的伝播経路が異なっており，圧 痕下の压縮応力場におけるき裂は表面近傍での粒界や 粒内などの粒径程度の割れが繰返し負荷により合体し， 


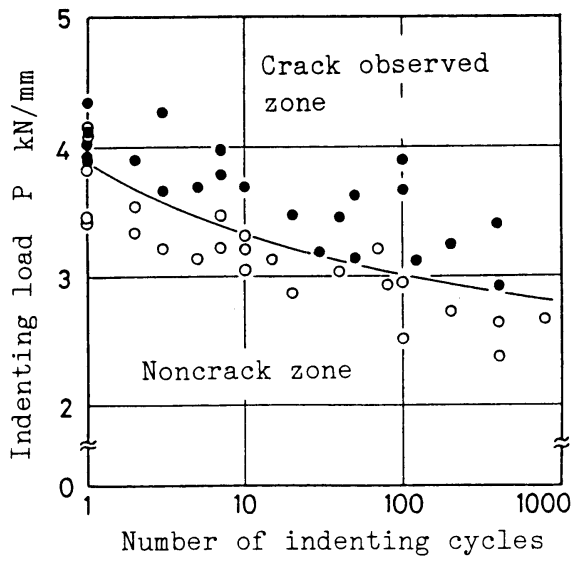

Fig.8 The limit of crack occurrence in indenting test Tool material; $\mathrm{P} 20$

これを起点としてより大きなき袈に成長したものと考 えられる。

\section{2 裂発生限界}

冈8は押込み荷重および押込み繰返し数を任意に設 定し, 試験後の顕微鏡親察により区痕外側でのき裂発 生の有無を求めた結果である，同図中，○印がき裂が 観察された場合であり，○印は钼察されない場合で， 荷重は単位幅当たりについて示している。ここで押込 み繰返し数の上限はぜい性損傷による工具寿命の検討 を目的としていることから $10^{3}$ 回とした，同场より， 同一繰返し数でき裂が観察される荷重にばらつきがあ るが，平均的には図中に示す実線より大きい荷重でき 裂が発生するといえる．また，このき裂の発生する荷 重が繰返し数の增加とともに減少していることがわか る.ここではこのき裂の発生する荷重をき裂発生限界 荷重と呼ぶ．き裂発生限界荷重のばらつきは超硬合金 が微視的に不均質な組織であり，粒度分布や粒界など の局所的な組織の状態によるものと考えられる．また 繰返し数の增加による荷重の低下は軟質なCo相内で塑 性変形を生じることが一因と考えられる。

\section{3 裂発生限界荷重に及ぼす影響}

まず，表面性状のき裂発生限界荷重に及ぼす影響を 検討した結果が目9である。困は睡入状態とその表面 を $0.1 ， 0.15 \mathrm{~mm}$ 研削したもの, および $800^{\circ} \mathrm{C}, 1 \mathrm{~h}$ 真 空焼きなましした場合について比較したもので，研削 はダイヤモンド䃨石, 切込み $2 \mu \mathrm{m}$ ，送り $2 \mathrm{~m} / \mathrm{min}$, 砫 石周速 $1600 \mathrm{~m} / \mathrm{min} て ゙$ 行った. なお，いずれもき裂観察 の容易さから多イヤモンドペーストで鏡面仕上を施し ており，焼きなましについてはその後行っている。

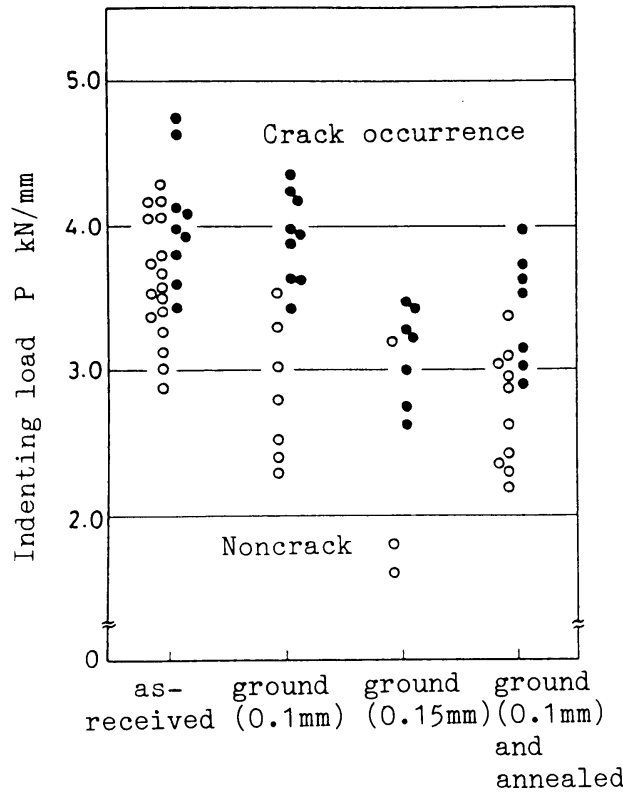

Fig.9 Effect of the surface preparation on the crack occurrence limit Tool material; $\mathrm{K} 10 \mathrm{~B}$

同図より，0.15mm研削あるいは焼さなましによりき 裂発生限界荷重が䑏入状態に比べ明らかに低下してい ることがわかる．一般的には研削加工により表面に圧 樎応力が残留すると考えられ6)，圧痕外側のき裂発生 領域は引張応力場となることから，压栯残留応力があ る場合にはき裂を発生し難くなる4)、購入状態ではこ の残留応力が存在するものと推定され，き裂発生限界 荷重が焼きなましたものに比べ高くなっているものと 考えられる。一方，微小切込みによる研削により 150 $\mu \mathrm{m}$ 程度表面を除去すると焼きなまし試料に近づくこ とから，研削条件によっては残留応力の影響が小さく なると考えられる。

次に，工具材料の影響について检討した結果が図10 で，P10，P30種以外については繰返し荷重を与えてい る、まず，各工具材料間のき裂発生限界荷重の大きさ に差があり，繰返し数 1 回の場合 $\mathrm{K} 10 \mathrm{~A}, \mathrm{P} 20, \mathrm{~K} 10 \mathrm{~B}, \mathrm{P}$ 10, P30 の順にき裂発生限界荷重が小さくなっている. また，P20種と $\mathrm{K} 10$ 種の比較から，材料により荷重繰 返しの影響が異なり，P20種の方が繰返し数に対する き裂発生限界荷重の低下が大きいことがわかる。さら に, 平均粒度が異なる $\mathrm{K} 10 \mathrm{~A}, \mathrm{~K} 10 \mathrm{~B}$ 間では，粒径の小さ いK10Aの場合のき裂発生限界荷重が大きいことがかか る、粒径が小さい場合破塿じん性值は小さい77のに対 


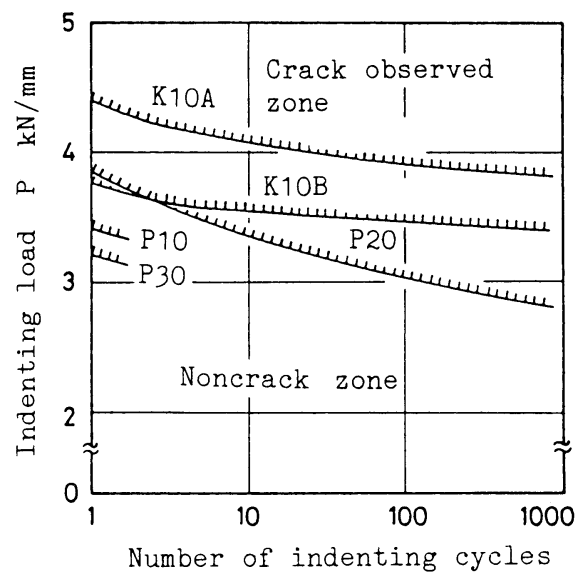

Fig.10 The limits of crack occurrence for various tool materials

し，き発生限界荷重では逆に上开している，他の工 具材料を含めたき裂発生限界荷重と破㙥し人性値との 阙保においても，例之ば，破噩し人性值の大きいP30 のき裂発生限界荷重は小さく，前述の表面性状の影䇾 も考之られるが，き裂発生限界荷重が巨視的な破烄し ん性值とは異なる特性に基づくとも考えられる，以上 のことから，本手法の押込み試联によりき裂発生に対 する表面性状，工具材料などの影管を検出し得ること が理解される。

\section{4 き裂の発生挙助}

押込み試験時においては曲げ試姶時にみられるよう なポアや粗大粒子などの欠陥は観察されない，押込み 陚駰の場合の圧痕外側におけるき裂発生位貴は压痕極 近傍の狭い領域に限定される，例之ば K10種の場合， 压痕から0.1mm 以内にき裂が発生している。このこと から，ポアなどの欠陥が観察されない理由として，第 一には破丧の起点となるようなポアや粗大粒子の分布 密度が低く，押込み試联時のように限定された狭いき 裂発生領域に曲げ試聡時の破猿に関与するような欠陷 がある確事は小さいことが考えられる，また，超硬合 金のような焼結材料では粒界や界面などの局所的強度 が巨視的な強度や粒子そのものの強度より低く ${ }^{81}$ ，こ れらが破壇の起点として関与することが第二の理由と して考えられる。

破垻を伴わずにポアなどの欠陥を棁出する道当な方 法がないことから，破塥の発生位国が欠陷の分布に対 むするものと考之，曲げ試姶の場合について破塂の発 生位宣を整理した結果の一例が国11である，同図は三 点曲げ試駼時に欠陮が観察された位貫を引張応力側表 面上に示したものである．工具材料はK10Aで，試験片

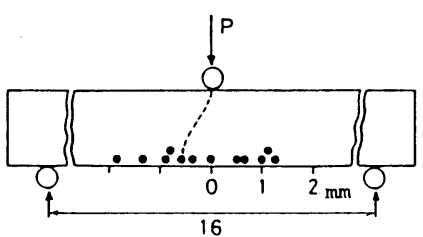

Fig.11 Crack initiation site in transverse test

Tool material; K10A

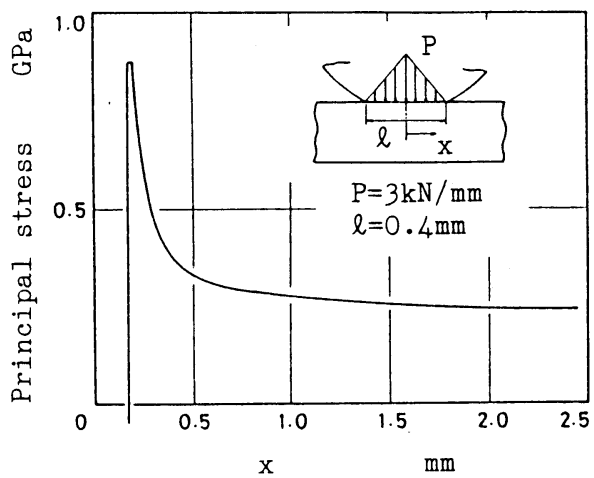

Fig.12 Distribution of principal stress along indented surface in indentation test

寸法は高さ $4 \mathrm{~mm}$, 幅 $2 \mathrm{~mm}$, 長さ $25 \mathrm{~mm}$, 支点間距離 $16 \mathrm{~mm}$

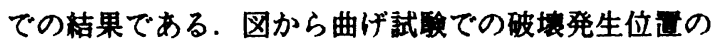
変化は押込み試姶時の $0.1 \mathrm{~mm}$ 以内に比べ 1 けた以上大 きいことがわかり，このことから押込み試畆時のき裂 発生位置にポアや粗大粒子などの破噩に関与する欠陥 がある確來は小さいと推定される.

また，図12は押込み試験時における試料表面での応 力分布について圧子と試料の接触領域の境界条件を図 中に示すように三角形状の分布として検討を行った一 例である．超硬合金P20(ヤング來 548.8GPa,ポアソン 比0.225)を想定し，要秦数1193で弾性平面Uずみ条件 での有限要素法による解析結果である，なお、圧子と 試料の接触幅は実签值を用いた。曲げ試聡では周知の ように両支点間で主応力は三角形分布となるが，押込 み試驓では図のように压痕外側近傍で芯力集中を示し このことが破賥の発生位雷が变化しない一因と考えら れる，すなわち，大きな応力集中を示す場合，破塔の 起点としてはポアや粗大粒子ではなく前述のように粒 界や界面など局所的に強度の低い領域が考えられる。 冈12の場合压痕近傍では $0.5 \mathrm{~mm}$ 以上觹れたところより 粎3 倍の大きな応力值を示すことからポアなどの大き さの $1 / 9$ 程度の粒界の大きさがあれば破堙の起点とな 
り得ることがわかる．この場合，境界条件や弾性変形 を仮定しているなど問題はあるが応力集中により粒界 や界面などの局所的な強度の低い領域でき裂を発生す ることが十分予测される。

一方，切削場においても工具一切りくず接触領域後 方のすくい面上で引張りの応力集中を生じると考えら れる.この応力集中によりき裂を発生するかどうかは 押込々試駧との応力値, 応力状㿟の比較が必要である が，欠損破面には多くの場合明らかな欠陷が観察され ないことから工具一切りくず接触領域後方のすくい面 上での応力集中により粒界や界面などの局所的な強度 の低い領域が欠損の起点となることが推定される。

以上のことから久陥の分布と応力分布状態が破俵発 生の微視的起点に大きな影響を持つことがわかる。し かしながら，これは引張応力場での検討であり，圧維 応力場については図7で述べたように粒径程度の小さ なき裂の発生と合体がみられることからこのことは さらに検討を要する.

\section{4. 結論}

切削工具材料を対象として, 押込る試験における破 嫂の発生挙動を検討し, 次の結果を得た.

（1）押込み試験におけるき裂は压痕外側において， 炭化物粒界あるいは炭化物と結合相との界面を伝 播し，圧子直下においては粒舅と粒内で粒界程度 の小さなさ列が覞察され，䊅返し負荷によりそれ らが合体することがわかった。

（2）圧痕外側でのき裂発生限界荷重は工具材料，表 面性状に依存するとともに，絽返し負荷によって 㳚少することがわかった.

（3）押込み試煖と曲げ試驓時の破俵発生の起点およ び応力分布の比較から，応力分布状態により破塿 の発生挙動が変化し, 引張応力場において応力集
中を示す場合には強度の低い粒界や界面を，応力 集中を示さない場合には粒径より大きいポアや粗 大粒子などの欠陷を起点として破壊を生じる.

（4）切削時においても工具一切りくず接触領域後方 のすくい面上で応力集中を生じることから，押込 み試験時と同㥞の破震発生機構が考えられ，界面 や粒界などの局所的に強度の低いところで欠損に 至るようなき裂を発生することが推定された。

䊏わりに，本研究は姫路工業大学在籍中に行ったも のであり，当時学生であった故森田満君に実験の協力 をいただいたことを記し，感謝とともに哀悼の意を表 する。

\section{参 考 文 献}

1) P. B.Anderson ; Hartmetalle erhohter Zahigke it, Planseeber. Pulvermet. . 15, (1967) 180.

2）大㚘悦夫，增田良道; 超硬合金の限界強度に関 する一考察，日本金属学会誌，47，12(1983) 1068.

3）柴坂敏郎，橋本英文，上田完次，岩田一明；切 削工具のぜい性損傷に関する破蜄力学的研究

（第2 報），精密機械，49,10（1983）1435.

4）例之ば，三次章義，原 昭夫，杉本良信; 超硬 合金におけるビッカース硬度圧浪周辺の裂の 娭討，日本金属学会誌，31，10(1967)1123.

5) T. R.Wilshaw ; The Hertzian Fracture Test, J. Phys. D: Appl. Phys. , 4, (1971) 1567.

6) H. E. Exner : The Influence of Sample Preparation on Palmqvist's Method for Toughness Testing of Cemented Carbides, Trans. AIME, 245, (1969) 677.

7) J. L. Chermant and F. 0sterstock: Fracture Toughness and Fracture of WC-Co Composites, J. Mater. Sci., 11, (1976) 1939.

8）大㚘悦夫，增田良道：NC-Co超硬合金のクラッラ 伝播経路，日本金属学会誌，44，2(1980) 117 . 